\title{
Isolation and Characterization of a Bacteriocin Produced by Pseudomonas solanacearum
}

\author{
By D. A. CUPPELS, * R. S. HANSON AND A. KELMAN \\ Departments of Bacteriology and Plant Pathology, \\ University of Wisconsin, Madison, Wisconsin 53706, U.S.A.
}

(Received 26 April 1978; revised 26 June 1978)

\begin{abstract}
Strain B1, an avirulent non-slime-producing variant of Pseudomonas solanacearum $\mathrm{K} 60$, had greater bacteriocinogenic activity than did strain $\mathrm{K} 60$ both in liquid and on solid medium. The bacteriocin synthesized by strain B1 inhibited the growth of 43 of $51 P$. solanacearum strains tested. It had no effect on strain $\mathrm{B} 1$, strain $\mathrm{K} 60$, or selected strains from 10 other bacterial species. Although the optimal growth temperature for strain $\mathrm{B} 1$ was $32^{\circ} \mathrm{C}$, the temperature most favourable for bacteriocin production was $30^{\circ} \mathrm{C}$. Bacteriocin titre could be increased by short exposure to ultraviolet light but not by chemical inducing agents.

The bacteriocin produced by strain $\mathrm{B} 1$ was purified from the culture supernatant by ammonium sulphate precipitation, anion exchange chromatography, membrane ultrafiltration and preparative electrophoresis. Purified bacteriocin, being non-sedimentable, thermolabile and sensitive to proteolytic enzymes, resembled the S-type bacteriocins produced by $P$. aeruginosa. As determined by sodium dodecyl sulphate-polyacrylamide gel electrophoresis, the purified bacteriocin had a molecular weight of approximately 65000 . It was insensitive to chloroform, nucleases and phospholipase. Although the bacteriocin present in culture supernatant was stable for 3 months at $4{ }^{\circ} \mathrm{C}$, the activity of purified bacteriocin declined rapidly under a variety of storage conditions. Maximum $\mathrm{pH}$ stability was between 6 and 8 .
\end{abstract}

\section{INTRODUCTION}

Several bacterial plant pathogens synthesize bacteriocins, proteinaceous bactericidal agents that act specifically on strains of the same or closely related species (Echandi, 1976; Nakatani \& Tsuyama, 1974; Vidaver et al., 1972). However, only one of these bacteriocins has been isolated and characterized: syringacin 4A from Pseudomonas syringae (Haag \& Vidaver, 1974).

Bacteriocin-like substances were first reported for the wilt pathogen, Pseudomonas solanacearum, by Okabe (Okabe, 1954). Ten of the 40 strains that Okabe had used to study lysogeny were sensitive to agents that diffused from the clones of five producer strains. For these strains, production of and sensitivity to the antibiotic-like compounds did not correlate with degree of virulence or host range (Okabe \& Goto, 1961).

Pseudomonas solanacearum is pathogenic for many different species of plants in over 33 genera. As yet, no classification scheme based on laboratory-determined characteristics adequately defines the pathogenic profile of the various strains. Thus, a more comprehensive investigation into the nature of the bactericidal substances synthesized by this important plant pathogen might prove very useful. In addition, the bacteriocins have potential value as biological control agents (Vidaver, 1976).

The objectives of the present study were, firstly, to determine the optimal conditions for

* Present address: Department of Plant Pathology, University of Nebraska, Lincoln, Nebraska 68583, U.S.A. 
Table 1. Pseudomonas solanacearum indicator strains used

\begin{tabular}{|c|c|c|c|}
\hline $\begin{array}{c}\text { Strain } \\
\text { no. }\end{array}$ & Host plant & $\begin{array}{c}\text { Region of origin } \\
\text { (Donor + donor's designation) }\end{array}$ & $\begin{array}{l}\text { Isolation } \\
\text { date }\end{array}$ \\
\hline 3 & Banana & Armuelles, Panama (Sequeira S107) & 1959 \\
\hline 23 & Potato & Israel (Volcani) & 1955 \\
\hline 26 & Tomato & Georgia, U.S.Á. (Kelman K74) & 1954 \\
\hline 27 & Tobacco & Florida, U.S.A. (Kelman, K105) & 1955 \\
\hline 28 & Potato & Cyprus (Dowson) & 1955 \\
\hline 37 & Potato & Bogota, Colombia (Thurston) & 1960 \\
\hline 40 & Banana & LaLima, Honduras (Buddenhagen) & 1960 \\
\hline 70 & Plantain & Ibague, Colombia (Thurston 23) & 1965 \\
\hline 71 & Plantain & Ibague, Colombia (Thurston 24) & 1965 \\
\hline 85 & Tomato & Canada (Layne 12A) & 1967 \\
\hline 135 & Banana & Buena Vista, Honduras (Berg 5513-4) & 1964 \\
\hline 143 & Tomato & Nambour, Australia (Hayward 002a) & 1965 \\
\hline 267 & Tomato & Taipei, Taiwan (Mew) & 1974 \\
\hline
\end{tabular}

production of bacteriocin-like compounds by $P$. solanacearum and, secondly, to isolate one such compound from the neotype strain of the species, $\mathrm{K} 60$. A preliminary report on this investigation has been presented (Cuppels et al., 1975).

\section{METHODS}

Bacterial strains. Pseudomonas solanacearum $\mathrm{K} 60$ was isolated from tomato by A. Kelman (Husain \& Kelman, 1958). The avirulent form of $\mathrm{K} 60$, strain $\mathrm{B} 1$, was obtained by a procedure described previously (Kelman \& Hruschka, 1973). The $P$. solanacearum strains used as indicators of bacteriocinogenic activity are listed in Table 1.

Several bacterial species other than $P$. solanacearum were tested for sensitivity to $P$. solanacearum bacteriocin. The following strains were obtained from the stock culture collection maintained in the Department of Plant Pathology at the University of Wisconsin-Madison: Erwinia carotovora var. atroseptica SR8; E. carotovora var. carotovora SR 38, SR34, SR204, SR117, SR40 and SR53; E. chrysanthemi SR29 and the corn pathotypes SR 78, SR61, SR 120 and SR90; Pseudomonas marginalis M13 and Mn12; P. syringae $\mathrm{W} 3$. Three cultures came from the Wisconsin State Laboratory of Hygiene: Enterobacter cloacae 15-561; Escherichia coli 86015; Serratia marcescens 11771. Pseudomonas aeruginosa PA08 and R3725 were supplied by B. Holloway. Three cultures from the stock culture collection of the Department of Bacteriology at the University of Wisconsin-Madison were also used: Salmonella enteritidis; Salmonella sp. 1061; Staphylococcus aureus FDA209.

Culture media. Strains were grown routinely in Casamino acids/peptone/glucose broth (CPG broth) containing ( $\left.\mathrm{g}^{-1}\right)$ : Bacto-peptone (Difco), 10; glucose, 10; Bacto-Casamino acids (Difco), 1. Other media used were CPG agar [CPG broth supplemented with $1.5 \%$ (w/v) Bacto-agar (Difco)], CPG soft agar [CPG broth plus 0.6\% (w/v) Bacto-agar] and TZC agar (Kelman, 1954).

Bacteriocin production and assay procedure. CPG broth $(10 \mathrm{ml}$ in a $125 \mathrm{ml}$ flask) was inoculated with the producer strain to a final concentration of $5 \times 10^{6}$ bacteria $\mathrm{ml}^{-1}$. After 12 to $16 \mathrm{~h}$ incubation $\left(30^{\circ} \mathrm{C}\right.$, aerobic conditions), mitomycin C (Nutritional Biochemicals) was added to the culture (final concentration $1 \mu \mathrm{g}$ $\mathrm{ml}^{-1}$ ). The culture was incubated in the dark for an additional $4 \mathrm{~h}$ before being treated with chloroform (final concentration $5 \%, \mathrm{v} / \mathrm{v}$ ). The chloroform/culture mixture was shaken vigorously for $60 \mathrm{~s}$ and then incubated for $4 \mathrm{~h}$ at $21^{\circ} \mathrm{C}$. A sample taken from the aqueous layer was diluted 1:100 in sterile distilled water. Lawns of the indicator organism were spotted with $0.02 \mathrm{ml}$ each of the diluted and undiluted aqueous sample. The indicator lawn was prepared by adding $10^{7}$ bacteria of the indicator strain to $3.5 \mathrm{ml} \mathrm{CPG} \mathrm{soft}$ agar (molten and at $50^{\circ} \mathrm{C}$ ) and then pouring the soft agar over a CPG agar plate. The assay plates were incubated for $24 \mathrm{~h}$ at $32^{\circ} \mathrm{C}$. Bacteriocin concentration was measured in terms of arbitrary units (AU) $\mathrm{ml}^{-1}$. The $\mathrm{AU} \mathrm{ml} \mathrm{m}^{-1}$ of a particular preparation was the reciprocal of the highest dilution that gave a clear zone of inhibition on an indicator lawn.

Determination of bacteriocin production by individual colonies. Pseudomonas solanacearum, diluted serially in sterile distilled water, was added to moiten $\left(50^{\circ} \mathrm{C}\right) \mathrm{CPG}$ soft agar, which then was poured over the surface of TZC agar. Soft agar was poured over the hardened inoculated soft agar to prevent spreading of colonies. As soon as individual colonies became visible $\left(36\right.$ to $48 \mathrm{~h}$ at $32^{\circ} \mathrm{C}$ ), a third portion of soft agar, inoculated with the indicator strain, was poured over the plate. Bacteriocin production by the colonies was visible within $24 \mathrm{~h}$. 
Preparation and purification of bacteriocin from Pseudomonas solanacearum. Strain B1 was grown in 0.51 CPG broth (21 flask) on a rotary shaker at $29^{\circ} \mathrm{C}$ for $14 \mathrm{~h}$. This culture $\left(5 \times 10^{\circ}\right.$ bacteria ml $\left.{ }^{-1}\right)$ served as inoculum for $121 \mathrm{CPG}$ broth containing $1.2 \mathrm{ml}$ antifoam B emulsion (Sigma) (final concentration $2 \times 10^{8}$ bacteria $\mathrm{ml}^{-1}$ ) which was aerated vigorously in a New Brunswick Microferm 141 fermenter (400 rev. $\mathrm{min}^{-1}$ at $30^{\circ} \mathrm{C}$ ). After $12 \mathrm{~h}$ incubation, when the density had reached $10^{10}$ bacteria $\mathrm{ml}^{-1}$, the fermenter was connected to a reservoir of CPG broth. As CPG broth was pumped into the fermenter at the rate of $41 \mathrm{~h}^{-1}$, the culture was pumped out and cooled to $4{ }^{\circ} \mathrm{C}$. After $10.5 \mathrm{~h}, 541$ of culture had been collected. The bacteria were sedimented in a Sharples continuous flow centrifuge and then frozen at $-20^{\circ} \mathrm{C}$. The volume of the supernatant, which initially contained $200 \mathrm{AU}$ bacteriocin $\mathrm{ml}^{-1}$ (assayed on strain 40 ), was reduced immediately to 21 by means of a Mojonnier evaporator. The following enzymes were then added: DNAase (DN-25; Sigma) dissolved in $0.01 \mathrm{M}$-Tris $/ 0.2 \mathrm{M}-\mathrm{NaCl}, \mathrm{pH} 8.0$ (final concentration $10 \mu \mathrm{g} \mathrm{m}^{-1}$ ), RNAase T1 (RT1

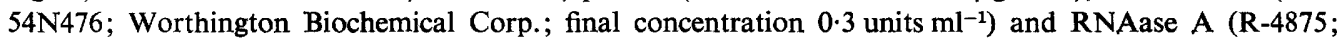
Sigma; final concentration $\left.1 \mu \mathrm{g} \mathrm{m}^{-1}\right)$. The preparation was dialysed against buffer $(0.01 \mathrm{M}-\mathrm{Tris} / 0.02 \mathrm{M}-$ $\mathrm{NaCl}, \mathrm{pH} 8.0$ ) for $3.5 \mathrm{~h}$ at $21^{\circ} \mathrm{C}$ and then against distilled water $\left(\mathrm{pH} \mathrm{7.1)}\right.$ for $12 \mathrm{~h}$ at $4{ }^{\circ} \mathrm{C}$. All subsequent steps were performed at $4{ }^{\circ} \mathrm{C}$. The bacteriocin preparation, which had increased in volume to 3.61 during dialysis, was clarified twice by centrifuging at $12000 \mathrm{~g}$ for $15 \mathrm{~min}$. The buffer concentration was adjusted to $0.05 \mathrm{M}$ with $1 \mathrm{M}$-potassium phosphate buffer, $\mathrm{pH} 7 \cdot 3$. The preparation was eluted twice from $15 \times 4.5 \mathrm{~cm}$ columns of DE52 (Whatman column chromedia, preswollen, anion-exchange cellulose) with 1.51 of $0.05 \mathrm{M}-$ potassium phosphate buffer, $\mathrm{pH} 7 \cdot 3$. None of the bacteriocin was retained on the column. The bacteriocin solution was clarified by centrifuging and then fractionated by ammonium sulphate precipitation into 0 to $25 \%$ and 25 to $45 \%$ precipitates. The precipitates were resuspended in $120 \mathrm{ml} 0.05 \mathrm{M}$ potassium phosphate buffer, $\mathrm{pH} 7 \cdot 3$. The solutions were dialysed against $0.05 \mathrm{M}$-potassium phosphate, $\mathrm{pH} 7 \cdot 3$, for $12 \mathrm{~h}$ and filter-sterilized. The 0 to $25 \%$ fraction was not inhibitory for indicator strain 40 and was discarded. The 25 to $45 \%$ fraction $\left(2 \times 10^{4} \mathrm{AU} \mathrm{ml}^{-1}\right)$ was concentrated from $120 \mathrm{ml}$ to $8 \mathrm{ml}$ with a Diaflo ultrafiltration membrane XM50 (Amicon Corp.) and then filter-sterilized.

\section{Polyacrylamide gel electrophoresis}

(i) Preparative polyacrylamide gel electrophoresis. Gel preparation was essentially the same as that described for analytical gel electrophoresis by Maurer (1971). A Tris gel system in which the proteins were concentrated at $\mathrm{pH} 8.3$ and separated at $\mathrm{pH} 9.5$ (Jovin et al., 1964) was used. Once the tracking dye $\left[0.05 \%(\mathrm{w} / \mathrm{v})\right.$ bromphenol blue] had entered the separation gel, $5 \mathrm{mg}$ bacteriocin $\left(10^{5} \mathrm{AU}\right)$ in $1 \mathrm{ml}$ of stacking gel buffer containing $10 \%(\mathrm{v} / \mathrm{v})$ glycerol were applied to the surface of the stacking gel. The column was then subjected to electrophoresis for $20 \mathrm{~h}$ at $5 \mathrm{~mA}$ and $450 \mathrm{~V}$. A Buchler fractionator set at $20 \mathrm{~min}$ per fraction was used to collect 70 fractions after the marker dye had eluted from the column. Each fraction was assayed for protein and inhibition of indicator strain 40 .

(ii) Analytical disc gel electrophoresis. The gel system consisted of a $7 \cdot 5 \%(\mathrm{w} / \mathrm{v})$ polyacrylamide (medium pore) separation gel $(7 \times 0.5 \mathrm{~cm})$ prepared in $0.38 \mathrm{M}-\mathrm{Tris} / \mathrm{HCl}, \mathrm{pH} 8.8$, and a $2.5 \%(\mathrm{w} / \mathrm{v})$ polyacrylamide (large pore) stacking gel $(1 \times 0.5 \mathrm{~cm})$ prepared in a buffer containing $0.06 \mathrm{M}$-Tris and $0.032 \mathrm{M}-\mathrm{H}_{3} \mathrm{PO}_{4}, \mathrm{pH} 6.9$. The reservoir buffer was $0.005 \mathrm{M}$-Tris and $0.038 \mathrm{M}$-glycine, pH 8.3. After electrophoresis (4 mA per gel, $4 \mathrm{~h}, 4{ }^{\circ} \mathrm{C}$ ), the gels were either stained with Coomassie blue or sliced and assayed for bacteriocin activity. The procedure of Fairbanks et al. (1971) was employed for staining and destaining the gels. Gels to be assayed for bacteriocin activity were sliced into $1 \mathrm{~mm}$ slices and each slice was incubated at $4{ }^{\circ} \mathrm{C} \mathrm{for} 12 \mathrm{~h}$ in $0.2 \mathrm{ml} 0.09 \mathrm{M}$-Tris $/ \mathrm{HCl}, \mathrm{pH} 8 \cdot 1$. The material eluted from each slice was then assayed for activity using indicator strain 40.

(iii) Sodium dodecyl sulphate-polyacrylamide gel electrophoresis. Polyacrylamide gels with a sodium dodecyl sulphate (SDS) buffer were prepared as described by Laemmli (1970). Proteins used as standards for the molecular weight determination were : trypsin (23800 mol. wt, Calbiochem), ribonuclease $(13700 \mathrm{~mol}$. wt, ICN-Nutritional Biochemicals), lysozyme (17500 mol. wt, ICN-Nutritional Biochemicals), cytochrome $c$ (12400 mol. wt, a Schwartz-Mann non-enzymic protein molecular weight marker) and crystalline bovine albumin (67000 mol. wt, ICN-Pharmaceuticals).

Protein determination. The amount of protein in a bacteriocin extract was determined by means of the Folin phenol reagent (Lowry et al., 1951) for crude extracts or by absorption at $280 \mathrm{~nm}$ (Mayr-Harting et al., 1972) for purified preparations.

Agarose gel filtration. A jacketed column was packed with Bio-Rad Bio-Gel A-1.5 m, 100 to 200 mesh, agarose $(8 \%, \mathrm{w} / \mathrm{v})$ to a height of $59.5 \mathrm{~cm}\left(1.5 \mathrm{~cm}\right.$ diam.) and cooled to $8{ }^{\circ} \mathrm{C}$. The void volume $\left(V_{0}\right)$ was determined with $0.025 \%(\mathrm{w} / \mathrm{v})$ Blue dextran. The elution volumes $\left(V_{\mathrm{e}}\right)$ of four non-enzymic protein molecular weight markers (Schwartz-Mann no. 908109) were used to prepare a molecular weight standard curve: horse apo-ferritin (490000 mol. wt), gamma-globulin (160000 mol. wt), ovalbumin (45000 mol. wt) and myoglobin (17000 mol. wt). 
Sensitivity of $\boldsymbol{P}$. solanacearum bacteriocin to enzymes. Bacteriocin purified by preparative gel electrophoresis $\left[2 \times 10^{4} \mathrm{AU}\left(\mathrm{mg}\right.\right.$ protein) $\left.{ }^{-1}\right]$ was diluted in $0.005 \mathrm{M}$-Tris $/ 0.39 \mathrm{M}$-glycine buffer containing $30 \%$ $(\mathrm{w} / \mathrm{v})$ glycerol, $\mathrm{pH} 8 \cdot 1$, to $50 \mathrm{AU} \mathrm{ml}^{-1}$. Samples $(1 \mathrm{ml})$ were treated for $90 \mathrm{~min}$ at $30^{\circ} \mathrm{C}$ with one of the following enzymes: DNAase (10 $\mathrm{g}$ plus $\left.10 \mathrm{~mm}-\mathrm{MgSO}_{4}\right)$, RNAase (50 $\mu \mathrm{g}$ RNAase A plus 6 units RNAase $\mathrm{T} 1$ ), trypsin $(50 \mu \mathrm{g})$, pronase ( $50 \mu \mathrm{g}$ plus $0.01 \mathrm{M}-\mathrm{CaCl}_{2}$ ), pepsin $\left(50 \mu \mathrm{g}\right.$ plus $\left.10 \mathrm{mM}-\mathrm{MgSO}_{4}\right)$ and phospholipase

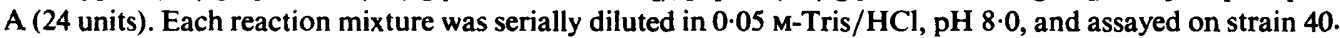

Sensitivity of $P$. solanacearum bacteriocin to chloroform. Bacteriocin $\left(10 \mathrm{AU} \mathrm{ml}^{-1}\right)$ eluted from an $8 \%$ $(\mathrm{w} / \mathrm{v})$ agarose column was treated with $1 \%(\mathrm{v} / \mathrm{v})$ chloroform for $60 \mathrm{~min}$ at $21{ }^{\circ} \mathrm{C}$; the chloroform was then removed by evaporation. The sample was filter-sterilized and then its inhibitory activity for strain 40 was compared with that of untreated bacteriocin held at $21^{\circ} \mathrm{C}$ for $60 \mathrm{~min}$.

\section{RESULTS}

\section{Cultural conditions for production of bacteriocin-like compounds by P. solanacearum $\mathrm{K} 60$}

The abundant slime that $P$. solanacearum formed when grown on solid media (Husain \& Kelman, 1958) prevented the detection of bacteriocin production by standard methods (Mayr-Harting et al., 1972; Gillies \& Govan, 1966). However, reproducible patterns of bacteriocin production were obtained when $P$. solanacearum was grown aerobically in a nutritionally rich liquid medium. In CPG broth the highest bacteriocin titre occurred during the late-exponential phase of growth: $50 \mathrm{AU} \mathrm{ml}^{-1}$ as measured with indicator strain 40 or $10 \mathrm{AU} \mathrm{ml}^{-1}$ as measured with indicator strain 143 . Growth of strain $\mathrm{K} 60$ in the following complex media failed to increase the titre: CPG1 broth (same as CPG but with glycerol in place of glucose), trypticase soy broth (Difco), nutrient broth (Difco; $1: 1$ dilution of the manufacturer's recipe) and TDY broth $[1 \%(\mathrm{w} / \mathrm{v})$ tryptone, $1 \%(\mathrm{w} / \mathrm{v})$ dextrose and $0.1 \%(\mathrm{w} / \mathrm{v})$ yeast extract].

In liquid medium, an avirulent non-slime-producing variant of $P$. solanacearum $\mathrm{K} 60$, designated $\mathrm{Bl}$, consistently released larger quantities of bacteriocin-like compounds than did $\mathbf{K} 60$. Isolated colonies of $\mathbf{B} \mathbf{l}$ were surrounded by significantly larger zones of inhibition than were isolated colonies of $\mathrm{K} 60$. Although the bacteriocin titre in CPG broth for both $\mathrm{K} 60$ and $\mathrm{Bl}$ was higher with indicator strain 40 (50 and $100 \mathrm{AU} \mathrm{ml}^{-1}$, respectively) than with indicator strain 143 (10 and $50 \mathrm{AU} \mathrm{ml}^{-1}$, respectively), the zones of inhibition around producer colonies on CPG agar were much larger with indicator strain $143(9 \cdot 2 \pm 0.9$ and $12.3 \pm 0.8 \mathrm{~mm}$, respectively) than with indicator strain $40(3.0 \pm 0.7$ and $5.6 \pm 0.6 \mathrm{~mm}$, respectively).

Fifty-one $P$. solanacearum strains were tested as indicators of the ability of strains $\mathrm{K} 60$ and Bl to release bacteriophage or bacteriocin-like compounds. Although several other strains of $P$. solanacearum release bacteriophage in the presence of mitomycin C (Cuppels, 1976), strains $\mathrm{K} 60$ and $\mathrm{B} 1$ do not. If bacteriophage had been present in the test culture supernatants, the serial dilutions made of the supernatants would have resulted in the appearance of discrete plaques on the appropriate indicator strain. Bacteriocin from strain Bl inhibited 43 strains, whereas that from strain K60 inhibited only 39 strains (Cuppels, 1976). Strains К 60 and в 1 were sensitive to agents produced by the same 20 strains, out of 46 other $P$. solanacearum strains tested. Neither strain was inhibited by its own bacteriocin.

The bacteriocin titres of strain $\mathbf{B} 1$ grown at five different temperatures using indicator strains 40 and 143 were, respectively: $25^{\circ} \mathrm{C}, 200$ and $100 \mathrm{AU} \mathrm{ml}^{-1} ; 30^{\circ} \mathrm{C}, 500$ and $100 \mathrm{AU}$ $\mathrm{ml}^{-1} ; 32{ }^{\circ} \mathrm{C}, 100$ and $50 \mathrm{AU} \mathrm{ml}^{-1} ; 34^{\circ} \mathrm{C}, 10$ and $0 \mathrm{AU} \mathrm{ml}^{-1} ; 38^{\circ} \mathrm{C}, 0$ and $0 \mathrm{AU} \mathrm{ml}^{-1}$. Although the optimal temperature for growth of strain $\mathrm{Bl}$ was $32{ }^{\circ} \mathrm{C}$, the temperature most favourable for bacteriocin production was $30^{\circ} \mathrm{C}$. When producer strains $\mathrm{K} 60$ (tomato isolate), Bl and 40 (banana isolate) were grown at $30^{\circ} \mathrm{C}$ instead of $32{ }^{\circ} \mathrm{C}$, they inhibited additional $P$. solanacearum strains (Table 2). The incubation temperature for bacteriocin production in all subsequent assays was $30^{\circ} \mathrm{C}$.

Addition of mitomycin $\mathrm{C}\left(0.4,1,2\right.$ or $\left.5 \mu \mathrm{g} \mathrm{ml}^{-1}\right)$, chloramphenicol $\left(150 \mu \mathrm{g} \mathrm{ml}^{-1}\right)$ or trimethoprim $\left(1,2\right.$ or $\left.5 \mu \mathrm{g} \mathrm{ml}^{-1}\right)$ to exponentially growing cultures of strains $\mathrm{K} 60$ or $\mathrm{B} 1$ 
Table 2. Sensitivity of 28 Pseudomonas solanacearum strains to bacteriocins produced by strains $\mathrm{K} 60, \mathrm{~B} 1$ and 40 , grown at 30 and $32^{\circ} \mathrm{C}$

The three producer strains were grown aerobically for $14 \mathrm{~h}$ in $10 \mathrm{ml}$ CPG broth ( $125 \mathrm{ml}$ flask) on a water-bath shaker set at 30 or $32^{\circ} \mathrm{C}$. Filter-sterilized supernatants of the cultures were spotted on to lawns of the indicator strains.

\begin{tabular}{|c|c|c|c|c|c|c|}
\hline \multirow[b]{3}{*}{$\begin{array}{l}\text { Producer } \\
\text { strain }\end{array}$} & \multicolumn{6}{|c|}{ No. of bacteriocin-sensitive strains in indicator group } \\
\hline & \multicolumn{2}{|c|}{$\begin{array}{c}\text { Tomato-Tobacco } \\
*(12)\end{array}$} & \multicolumn{2}{|c|}{$\begin{array}{c}\text { Banana-Plantain } \\
\text { (8) }\end{array}$} & \multicolumn{2}{|c|}{$\begin{array}{l}\text { Potato } \\
(8)\end{array}$} \\
\hline & $30^{\circ} \mathrm{C}$ & $\overline{32{ }^{\circ} \mathrm{C}}$ & $30^{\circ} \mathrm{C}$ & $\widehat{32{ }^{\circ} \mathrm{C}}$ & $30^{\circ} \mathrm{C}$ & $32^{\circ} \mathrm{C}$ \\
\hline $\begin{array}{l}\text { K60 (tomato) } \\
\text { B1 } \\
40 \text { (banana) }\end{array}$ & $\begin{array}{l}6 \\
9 \\
9\end{array}$ & $\begin{array}{l}4 \\
8 \\
6\end{array}$ & $\begin{array}{l}7 \\
7 \\
6\end{array}$ & $\begin{array}{l}6 \\
6 \\
3\end{array}$ & $\begin{array}{l}6 \\
6 \\
5\end{array}$ & $\begin{array}{l}6 \\
6 \\
4\end{array}$ \\
\hline
\end{tabular}

* Numbers in parentheses indicate the number of strains in each indicator group tested for bacteriocin sensitivity.

Table 3. Preliminary steps in the purification of bacteriocin from the culture supernatant of Pseudomonas solanacearum $\mathrm{B} 1$

Step

(1) Supernatant

(2) Concentrated

supernatant

(3) Nucleases + dialysis

(4) DE52 column,

$0.05 \mathrm{M}$-potassium phosphate buffer, $\mathrm{pH} 7 \cdot 3$

(5) 25 to $45 \%$ ammonium

sulphate fraction

(6) Amicon XM50

concentration

$$
\begin{aligned}
& 10^{-3} \times \\
& \text { Activity* }
\end{aligned}
$$

$$
\text { (l) }
$$

50

2

$3 \cdot 6$

3.6

$0 \cdot 12$

0.008

$0 \cdot 2$

$5 \cdot 0$

$2 \cdot 5$

$2 \cdot 5$

20

300
(AU ml-1)

\section{Total}

activity

(AU)
10

10

9

9

$2 \cdot 4$

$2 \cdot 4$

$10^{-2} \times$
Total
protein

(mg)

二

1300
340

$10^{-3} \times$

Specific

activity Yield

$\left(\mathrm{AU} \mathrm{mg}^{-1}\right) \quad(\%)$

100

90

90

$\begin{array}{ll}0.07 & 90 \\ 0.27 & 90\end{array}$

* Bacteriocinogenic activity was measured in terms of arbitrary units, AU (the reciprocal of the highest dilution that gave an inhibition zone). The bacteriocin preparation was diluted in sterile distilled water and assayed on indicator strain 40 .

did not increase the bacteriocin titre of either strain more than twofold. However, short exposure of strain B1 to ultraviolet light $(366 \mathrm{~nm} ; 2$ min at a distance of $50 \mathrm{~cm}$ from a $4 \mathrm{~W}$ bulb) raised the titre 10 -fold, from 100 to $1000 \mathrm{AU} \mathrm{ml}^{-1}$, against indicator strain 40 . The titre against indicator strain 143 was unaffected by ultraviolet irradiation.

\section{Isolation of bacteriocin from P. solanacearum $\mathbf{B} 1$}

Pseudomonas solanacearum $\mathbf{B} 1$ bacteriocin was obtained as described in Methods. The initial steps in the purification of bacteriocin from the culture supernatant are summarized in Table 3. The activity of the compound was unaffected during concentration with the Mojonnier evaporator or treatment with nuclease. After centrifugation for $60 \mathrm{~min}$ at $34000 \mathrm{~g}$, less than $1 \%$ of the activity was sedimented.

The bacteriocin was further purified by preparative polyacrylamide gel electrophoresis. Approximately $10 \%\left(5 \times 10^{3} \mathrm{AU}\right)$ of the bacteriocin activity added to the column was recovered. Although the specific activity of bacteriocin was reduced from $10^{5}$ to $2 \times 10^{4} \mathrm{AU}$ (mg protein $)^{-1}$, its purity increased substantially as demonstrated by analytical disc gel electrophoresis (Fig. 1). The location of the two protein bands on a stained gel (Fig. 1 B) corresponded to the location of bacteriocin activity on an unstained gel (13 to $15 \mathrm{~mm}$ 


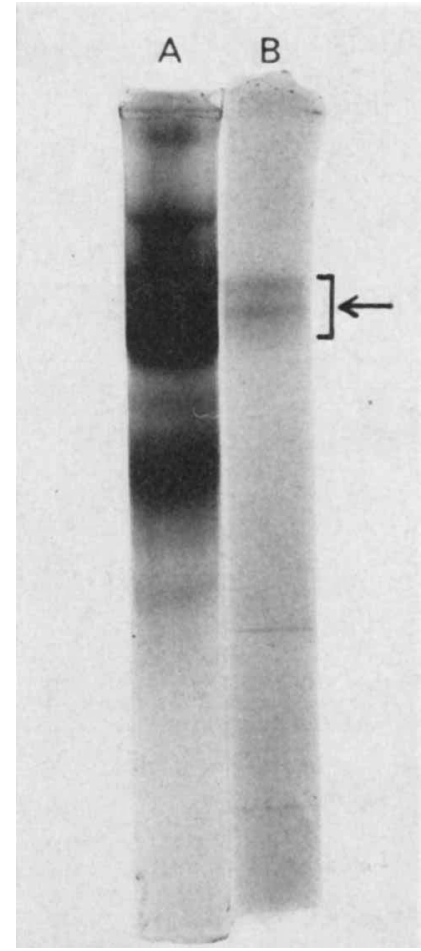

Fig. 1. Analytical disc gel electrophoresis [7.5\%(w/v) acrylamide; running $\mathrm{pH} 9.5]$ of a bacteriocin preparation before $\left(\mathrm{A} ; 140 \mu \mathrm{g}\right.$ step 6 material; $\left.1.4 \times 10^{4} \mathrm{AU}\right)$ and after $\left(\mathrm{B} ; 8 \mu \mathrm{g} ; 1.2 \times 10^{2} \mathrm{AU}\right.$ ) purification by preparative gel electrophoresis. The two gels (each $7 \mathrm{~cm}$ long) were not subjected to electrophoresis simultaneously. Bacteriocinogenic activity in gel B is indicated by the arrow. In gel $\mathrm{A}$, bacteriocinogenic activity occurred 6 to $8 \mathrm{~mm}$ from the top. The gels were stained for protein with Coomassie blue.

below the top of the separation gel). The purified bacteriocin extract was subjected to analytical disc gel electrophoresis three more times with the same results. In contrast, bacteriocin from the concentrated ammonium sulphate fraction (Step 6, Table 3) produced many bands on a stained gel (Fig. 1 A) and bacteriocin activity could not be identified with any distinct protein band(s).

The molecular weight of bacteriocin purified by preparative gel electrophoresis was estimated by SDS-polyacrylamide gel electrophoresis. As with the analytical gel, two protein bands were visible near the top of the gel. The molecular weights of these two bands calculated from a standard plot of $\log$ molecular weight $v$. relative electrophoretic mobility were 64000 and 66000 .

The molecular weight of the $P$. solanacearum $\mathbf{B} 1$ bacteriocin was also estimated by agarose gel filtration. Bacteriocin partially purified by the six steps listed in Table 3 was applied to an $8 \%(\mathrm{w} / \mathrm{v})$ agarose gel column (see Methods) and its molecular weight was calculated from its elution volume. The value obtained, 63000 , approximated to those determined from SDS-polyacrylamide gels for bacteriocin purified by preparative gel electrophoresis.

Purified bacteriocin eluted from the agarose column, like the supernatant from a strain B1 broth culture, was active against strains $3,23,27,28,37,40,70,71,85,135$ and 143. Unlike the supernatant, it was inactive against strains 267 and 26 . This difference, as in the case of colicins (McGeachie \& McCormick, 1967), could be explained by the difference in bacteriocin concentration used for the assays $\left(200 \mathrm{AU} \mathrm{ml}^{-1}\right.$ for the supernatant and $10 \mathrm{AU} \mathrm{ml}^{-1}$ for purified bacteriocin).

Bacteriocin in strain Bl culture supernatant passed through an Amicon XM100 filter 
(100000 molecular weight cut-off), but not an XM50 filter (50000 molecular weight cut-off). This estimate of molecular weight agreed well with those calculated using SDS-polyacrylamide gels and agarose gel filtration.

\section{Characterization of the P. solanacearum bacteriocin}

The bacteriocin titre of strain $\mathrm{B} 1$ culture supernatant was $200 \mathrm{AU} \mathrm{ml}^{-1}$ provided the $\mathrm{pH}$ of the supernatant remained between 6 and 8 . After $3 \mathrm{~h}$ incubation $\left(21^{\circ} \mathrm{C}\right)$ at $\mathrm{pH} 9$ or 5 , the titre dropped by $50 \%$, while at $\mathrm{pH} 3$ or 10 , bacteriocin activity disappeared completely. Bacteriocin in filter-sterilized culture supernatant $\left(200 \mathrm{AU} \mathrm{ml}^{-1}\right)$ retained full activity for 3 months at $4{ }^{\circ} \mathrm{C}$. However, the activity of purified bacteriocin declined rapidly at $4{ }^{\circ} \mathrm{C}(50 \%$ loss in $2 \mathrm{~d})$, whether in $0.05 \mathrm{M}$-Tris/ $\mathrm{HCl}\left(\mathrm{pH}_{2} 8\right), 0.05 \mathrm{M}$-Tris $/ 0.2 \mathrm{M}-\mathrm{NaCl}$ (pH 8.1), 0.005 M-Tris/0.39 M-glycine ( $\mathrm{pH} \mathrm{8.3)} \mathrm{or} \mathrm{0.01} \mathrm{M-potassium} \mathrm{phosphate} \mathrm{buffer} \mathrm{(pH} \mathrm{7.3).}$

Lyophilization in $0.05 \mathrm{M}-\mathrm{Tris} / \mathrm{HCl}(\mathrm{pH} \mathrm{8.0)}$ completely removed the activity of bacteriocin purified by preparative gel electrophoresis. When it was stored at $-20{ }^{\circ} \mathrm{C}$ in $30 \%(\mathrm{v} / \mathrm{v})$ glycerol, there was a $50 \%$ reduction in activity within 2 weeks. Dimethylsulphoxide $(5 \%$, $\mathrm{v} / \mathrm{v}$ ) increased the rate of loss of activity. Activity in purified preparations and in culture supernatants was lost completely when heated at $65^{\circ} \mathrm{C}$ for $10 \mathrm{~min}$. Bacteriocin purified by preparative gel electrophoresis was insensitive to DNAases, RNAase A and T1, phospholipase A, pepsin and chloroform. It was completely inactivated by pronase. Trypsin reduced the titre from 50 to $5 \mathrm{AU} \mathrm{ml}^{-1}$ in $90 \mathrm{~min}$ at $30^{\circ} \mathrm{C}$.

Four $P$. solanacearum strains ( $\mathrm{K} 60$ from tomato, 128 from plantain, 71 from banana and 120 from potato), representing the three $P$. solanacearum races and producing very different patterns of inhibition against $53 P$. solanacearum indicator strains (Cuppels, 1976), were unable to inhibit 23 strains selected from the following species: Erwinia carotovora var. atroseptica, E. carotovora var. carotovora, E. chrysanthemi, Enterobacter cloacae, Escherichia coli, Serratia marcescens, Salmonella enteritidis, Staphylococcus aureus, Pseudomonas marginalis, $P$. aeruginosa and $P$. syringae. Thus, the $P$. solanacearum bacteriocins appeared to be species-specific.

\section{DISCUSSION}

Syringacin 4A of $P$. syringae (Haag \& Vidaver, 1974), which resembles a bacteriophage tail, was the first bacteriocin produced by a phytopathogen to be thoroughly characterized. However, the $P$. solanacearum $\mathrm{B} 1$ bacteriocin was the first one to be isolated from a plant pathogen that belonged to the non-sedimentable, low molecular weight group (Bradley, 1967). It resembled pyocin S2 from $P$. aeruginosa (Ohkawa et al., 1973), the one other pseudomonad bacteriocin of this group that has been described.

Avirulent $P$. solanacearum $\mathrm{B} 1$ produced a higher titre of bacteriocin and inhibited more indicator strains than did its parent strain, $\mathrm{K} 60$, whose bacteriocinogenic activity might be masked by extracellular polysaccharide. Avirulent Bl was sensitive to the same bacteriocins or bacteriocin-like compounds as its virulent parent strain, K60, suggesting that pathogenicity was not associated with bacteriocin sensitivity, as in biotype 1 strains of Agrobacterium tumefaciens (Roberts \& Kerr, 1974).

Although easily inactivated during the purification process, the $P$. solanacearum $\mathrm{B} 1$ bacteriocin present in culture supernatant was stable and inhibited a large number of $P$. solanacearum strains. This bacteriocin and its avirulent producer, strain B1, could, therefore, be useful in the development of a bacteriocin-typing scheme for $P$. solanacearum or in the development of biological control measures for bacterial wilt.

Although the optimal growth temperature for $P$. solanacearum $\mathrm{K} 60$ and $\mathrm{B} 1$ was $32^{\circ} \mathrm{C}$, the optimal temperature for bacteriocin production was $30^{\circ} \mathrm{C}$ (Table 2). Similar observations were made concerning bacteriocin production by Pseudomonas aeruginosa (Gillies \& Govan, 1966) and $P$. syringae, $P$. glycinea and $P$. phaseolicola (Vidaver et al., 1972). 
The bacteriocin titre of a $P$. solanacearum $B 1$ culture could not be increased substantially by treatment with chemical inducing agents. The titre of cell-bound colicins controlled by the self-transmissible Col factors of the I and V group likewise cannot be induced (Herschman \& Helinski, 1967b), although Hardy \& Meynell (1972) suggested this might be because they had not been totally released from the cells by chloroform treatment. For P. solanacearum bacteriocin, $95 \%$ of the total yield was present in the culture supernatant; only $5 \%$ was released from lysozyme-treated cells.

A sample of bacteriocin purified by preparative electrophoresis produced two major bands, representing molecular weights of 66000 and 64000 , on SDS-polyacrylamide gels. Similar results had been obtained with colicin E2 by Herschman \& Helinski (1967a) but their bacteriocin existed as two electrophoretically distinguishable forms of the same molecule and not as two structurally distinct molecules. Whether the bacteriocin activity of $P$. solanacearum Bl is associated with one or two distinct bacteriocins cannot be determined until the two bands seen on SDS gels are separated.

Research supported by the College of Agricultural and Life Sciences, University of Wisconsin-Madison, and a grant from the National Science Foundation (BMS74-17442).

\section{REFERENCES}

BRADLEY, D. E. (1967). Ultrastructure of bacteriophages and bacteriocins. Bacteriological Reviews 31, 230-314.

CuPPELS, D. A. (1976). Bacteriocin production by Pseudomonas solanacearum. Ph.D. thesis, University of Wisconsin, U.S.A.

Cuppels, D., Hanson, R. \& Kelman, A. (1975). Production of bacteriocin-like compounds by Pseudomonas solanacearum. Proceedings of the American Phytopathological Society 2, 56-57 (abstract).

ECHANDI, E. (1976). Bacteriocin production by Corynebacterium michiganense. Phytopathology 66, 430-432.

Fairbanks, G., Steck, T. L. \& Wallach, D. F. H. (1971). Electrophoretic analysis of the major polypeptides of the human erythrocyte membrane. Biochemistry 10, 2606-2617.

Gillies, R. \& Govan, J. (1966). Typing of Pseudomonas pyocyanea by pyocine production. Journal of Pathological Bacteriology 91, 339-345.

HAaG, W. \& Vidaver, A. (1974). Purification and characterization of syringacin 4-A, a bacteriocin from Pseudomonas syringae 4-A. Antimicrobial Agents and Chemotherapy 6, 76-83.

Hardy, K. G. \& Meynell, G. G. (1972). Colicin factors and mitomycin C. Journal of General Microbiology 73, 547-549.

Herschman, H. R. \& Helinski, D. (1967a). Purification and characterization of colicin E2 and E3. Journal of Biological Chemistry 242, 5360 5368.

Herschman, H. R. \& Helinski, D. (1967b). Comparative study of the events associated with colicin induction. Journal of Bacteriology 94, 69I-699.

Husain, A. \& Kelman, A. (1958). Relation of slime production to mechanism of wilting and pathogenicity of Pseudomonas solanacearum. Phytopathology 48, 155-165.
Jovin, T., Chrambach, A. \& Naughton, M. A. (1964). An apparatus for preparative temperatureregulated polyacrylamide gel electrophoresis. Analytical Biochemistry 9, 351-369.

Kelman, A. (1954). The relationship of pathogenicity in Pseudomonas solanacearum to colony appearance on a tetrazolium medium. Phytopathology 44, 693-695.

Kelman, A. \& HruschKa, J. (1973). The role of motility and aerotaxis in the selective increase of avirulent bacteria in still broth cultures of Pseudomonas solanacearum. Journal of General Microbiology 76, 177-188.

LAEMMLI, U. (1970). Cleavage of structural proteins during the assembly of the head of bacteriophage T4. Nature, London 227, 680-685.

Lowry, O. H., Rosebrough, N. J., FarR, A.. L. \& RANDALl, R. J. (1951). Protein measurement with the Folin phenol reagent. Journal of Biological Chemistry 193, 265-275.

McGeachie, J. \& McCormick, W. (1967). Importance of potency in typing by colicine production. Journal of Clinical Pathology 20, 887-891.

MAURER, H. F. (1971). Disc Electrophoresis and Related Techniques of Polyacrylamide Gel Electrophoresis, 1st edn. New York: Walter de Gruyter.

Mayr-Harting, A., Hedges, A.J. \& Berkeley, R. C. W. (1972). Methods for studying bacteriocins. Methods in Microbiology 7A, 315-422.

Nakatani, F. \& Tsuyama, H. (1974). Production of two kinds of antibacterial agents by isolates of Erwinia carotovora. Journal of the Faculty of Agriculture, Iwate University 11, 245-253.

OhKawa, K., Kageyama, M. \& Egami, F. (1973). Purification and properties of pyocin S2. Journal of Biochemistry 73, 281-289.

OKABE, N. (1954). Studies on Pseudomonas solanacearum. V. Antagonism among the strains of $P$. solanacearum. Reports of the Faculty of Agriculture, Shizuoka University 4, 37-40. 
OKabe, N. \& Goto, M. (1961). Studies on P. Vidaver, A. K. (1976). Prospects for control of solanacearum. XI. Pathotypes in Japan. Reports of the Faculty of Agriculture, Shizuoka University $11,25-42$.

ROBERTS, W. \& KerR, A. (1974). Crown gall induction: serological reactions, isozyme patterns and sensitivity to mitomycin $\mathrm{C}$ and to bacteriocin, of pathogenic and nonpathogenic strains of Agrobacterium radiobacter. Physiological Plant Patho$\log y$ 4, 81-91.

phytopathogenic bacteria by bacteriophages and bacteriocins. Annual Review of Phytopathology 14, 451-465.

VidaVer, A. K., Mathys, M. L., Thomas, M. \& SCHUSTER, M. (1972). Bacteriocins of the phytopathogens Pseudomonas syringae, $P$. glycinea and $P$. phaseolicola. Canadian Journal of Microbiology 18, 705-713. 